\title{
The Degree of Applying Accountability Principles in Public \& Private Universities in Jordan: A Comparative Study Between Yarmouk University and Jerash University
}

\author{
Dr. Ahmed Malkawi \\ Prof. Kamil Al-Otoum \\ Jerash University, Jordan
}

doi: 10.19044/esj.2017.v13n4p253 URL:http://dx.doi.org/10.19044/esj.2017.v13n4p253

\begin{abstract}
The study aimed to identify the status of applying the principles of accountability in the public and private universities in Jordan. This was done by comparing between Yarmouk University and Jerash University from the perspective of the employees. The study sample consisted of 250 faculty members and one administrator at Yarmouk University and Jerash University. The questionnaire was used as a tool for data collection.

The study reached several conclusions, most notably of which include the presence of statistically significant differences in the reality of applying the accountability principles at universities in general, and in the administrative, and academic fields. This, however, is dependent on the variable of the university in favor of Jerash University. The study concluded on a number of recommendations most important of which is the necessity of activating the accountability mechanisms and tools in three areas: administrative, and academic areas of public universities in a higher degree. It also includes a commitment with unified criteria of accountability to ensure the maintenance of an acceptable level of justice and transparency.
\end{abstract}

Keywords: Accountability, universities of Jordan, Yarmouk University, Jerash University

\section{Introduction and Theoretical Framework}

Educational institutions and universities in particular at all levels need effective, targeted, and developed management. This is because the essence of management relies on the investment of human and material resources to achieve the desired goals in less effort and time. As a result, they need to apply the principles of accountability (Bajaria, 2011).

The concept of accountability is widely used in the literature of management and education; however, it still lacks an accurate conceptual 
definition and interferes with other concepts (Jamil, 2009). Juhani (2012, p. 18) has provided many definitions for accountability, including: "the user's ability to carry out specific functions and explain the gains achieved by it and the willingness to accept either blame for its failure or praise for its success ..." Al-Hassan $(2010,14)$ defined it by stating: "the user is responsible for the results of his work and providing answers or explanations of what he offers, and that there is a supervisory body to question him ....

Despite the importance of continuous follow-up and audit, accountability should not be seen as a source of fear or anxiety or a tool of threat, but rather should be seen as a method to review and improve performance, and develop the skills of employees in institutions. Kaltt (2002) set some benefits for efficiently applying accountability such as the focus of the educational institutions on strategic objectives, coordinating the efforts of teams and individuals, identifying the gaps in performance and repairing them, strengthening forms of support and partnership among employees, supporting the strategic thinking at the level of individuals and groups, promoting the good relations between managers and employees, giving more motivation to work and raise the level of expectations, and thus raises the level of performance, and pushing employees to improve the methods used at work.

Hawamdeh and Jaradat (2005) state the objectives of accountability such as directing the institution energies towards strategic goals, organizing individuals in accordance with the strategy of the institution, identifying the points of failure at work, and directing the staff focus on the results of their work...

Consequently, there are two main sources of accountability referred to by AlAllaq (2008): subjective and objective. The objective source has two sources: internal and external sources. The external is represented by the control agencies, while the internal is represented by the immediate manager. As for the subjective source, it is related to the values of which the individual believes.

Romzek et al. (2008) state the kinds of accountability: political, administrative, legal, professional, general social, and organizational. Despite this, it should be viewed as a means to achieve the best level of administrative performance as well as a value and means for continuous improvement.

\section{Previous Studies}

There are many studies on accountability, such as:

- Al-Douiri (2002) aimed to recognize the reality of accountability in the public administration in Jordan. It showed the existence of obstacles to activate accountability, lack of the support of leaders/senior management, 
weakness of the overall planning, weak protection afforded to employees, and the lack of certain criteria of accountability.

- Al-Subaie (2010) aimed to identify the level of the commitment of the public sectors in Riyadh through the application of accountability. It resulted in the fact that the level of public sectors' application of accountability in the KSA is low and that the level of modernizing systems and laws by such sectors is moderate.

- Gasman, (2010) found a set of conclusions that should be applied in universities. Hence, they include: the adoption of transparency, accountability, and participation in all the issues of the university. It also entails promoting the culture of dialogue and discussion between students and university leaders and administrators.

- Deboerm, Jeroen, and Scheytt (2010) examines the governments' control on universities through discussing the governance in three countries, namely: the Netherlands, Austria, and the United Kingdom. It was concluded that setting new structures for the governance of universities is one of the modern elements of repairing higher education in Europe.

- Harb (2011) aimed to identify the reality of the administrative transparency and the requirements of applying it by the senior management in the Palestinian universities in the Gaza Strip. It was concluded that there is a commitment with practicing the administrative transparency in an acceptable degree by both administrators and academics who occupy managerial positions in the Palestinian universities. Also, there was the presence of a statistically significant relationship between the fields of the study.

\section{Study Problem}

This study examines the reality of applying accountability in the Jordanian public and private universities to provide data for decision-makers about the reality, activation, and development of accountability in their organizations. This was done without subjecting the public and private institutions of higher education to the same criteria in order to be accountable in a fair and transparent way.

\section{Study Goal and Questions}

This study aimed to examine the reality of accountability in the Jordanian public and private universities, and figure out any differences among them. This objective is highlighted in three sub-questions, namely:

1. What is the degree of applying the principles of accountability at Yarmouk University from the perspective of employees at the university: teaching staff and administrators? 
2. What is the degree of applying the principles of accountability at Jerash University from the perspective of employees at the university: teaching staff and administrators?

3. Are there statistically significant differences between the two universities in the degree of applying the principles of accountability at the level of significance $\alpha \leq 0.05$ ?

\section{Study Importance}

However, the importance of this study is highlighted in the following aspects:

- Enriching the literature in the field of accountability at universities.

- Educating the administrative leaders at the universities with the reality of accountability, and its application mechanism at universities to reach the desired level of fairness and transparency.

- Increasing the interest of related agencies with applying accountability at universities in order to activate them.

\section{Study Limitations}

The results of this study are limited by the following:

Spatial Boundaries: This study was limited to Yarmouk University and Jerash University.

Temporal Boundaries: The study was conducted on employees at the two universities in the academic year 2015/2016.

Human Boundaries: The study included the employees in teaching and administration at the two universities.

\section{Study Methodology}

The study followed the descriptive analytical method using a questionnaire to detect the degree of accountability at Yarmouk University and Jerash University.

\section{Study Population and Sample}

The study population is the teaching staff and administrators at Yarmouk University and Jerash University in the academic year 2015/2016. The study sample consisted of 250 individuals who have been chosen from the teaching staff and administrators of the two universities. Table 1 shows the distribution of the members of the study sample according to the personal and functional variables. 
Table 1. The Distribution of the study sample according to the personal and functional variables

\begin{tabular}{|c|c|c|c|}
\hline Variables & Category & Frequency & Percent \\
\hline \multirow{3}{*}{ Workplace } & Yarmouk University & 150 & 60 \\
\hline & Jerash University & 100 & 40 \\
\hline & Total & 250 & 100 \\
\hline \multirow{5}{*}{ Age } & 20-29 years old & 56 & 22.4 \\
\hline & 30-39 years old & 99 & 39.6 \\
\hline & 40-49 years old & 57 & 22.8 \\
\hline & More than 50 years old & 38 & 15.2 \\
\hline & Total & 250 & 100 \\
\hline \multirow{5}{*}{$\begin{array}{c}\text { Scientific } \\
\text { Qualification }\end{array}$} & less than Bachelor & 33 & 13.2 \\
\hline & Bachelor & 90 & 36 \\
\hline & Master & 34 & 13.6 \\
\hline & PHD & 93 & 37.2 \\
\hline & Total & 250 & 100 \\
\hline \multirow{5}{*}{ Job Title } & faculty member & 86 & 34.4 \\
\hline & Department Director & 31 & 12.4 \\
\hline & Head of Department & 50 & 20 \\
\hline & Other & 83 & 33.2 \\
\hline & Total & 250 & 100 \\
\hline \multirow{6}{*}{ Experience (years) } & less than 5 years & 40 & 16 \\
\hline & 6-10 years & 43 & 17.2 \\
\hline & $11-15$ years & 63 & 25.2 \\
\hline & 16-20 Years & 55 & 22 \\
\hline & More than 21 years & 49 & 19.6 \\
\hline & Total & 250 & 100 \\
\hline
\end{tabular}

\section{The study Tool}

The study tool is a questionnaire, which is developed through reviewing the literature of the administrative and accounting sciences as well as the guide of the quality control criteria of the administrative sciences (2015) issued by the Higher Education Accreditation Commission. It consisted of 24 items distributed into two areas: the administrative and the academic areas in both the internal and external levels. Quintet Likert scale was used to measure the viewpoints of the members of the study sample as follows: very large (5) degrees, large (4), medium (3), little (2), and very little (1).

To achieve the validity of the study tool, it was presented to a group of specialists to ensure the adequacy and appropriateness of items to the subject of the study and its ability to collect the necessary data.

To calculate the reliability of the study tool, Cronbach's alpha was used on all the fields of the study and the tool as a whole. However, Table 2 illustrates this. 
Table 2. Cronbach's alpha reliability coefficients and the test-retest reliability coefficients for the areas of the study tool

\begin{tabular}{|c|c|c|c|}
\hline Test-retest reliability & $\begin{array}{c}\text { Number of } \\
\text { items }\end{array}$ & $\begin{array}{c}\text { Cronbach's alpha } \\
\text { coefficient }\end{array}$ & $\begin{array}{c}\text { The test-retest } \\
\text { reliability coefficient }\end{array}$ \\
\hline The administrative field & 6 & 0.76 & 0.77 \\
\hline The financial Field & 6 & 0.77 & 0.77 \\
\hline The academic field & 6 & 0.69 & 0.70 \\
\hline
\end{tabular}

Table 2 shows that the Cronbach's alpha coefficients were as follows: the administrative field (0.76), the financial field (0.77), and the academic field (0.69). Consequently, the test-retest reliability coefficient was as follows: the administrative field (0.77) and the financial field (0.77). In addition, the test-retest reliability coefficient for the academic field was 0.70 , which are acceptable for the purposes of the study. The Cronbach's alpha reliability coefficient is considered acceptable if it exceeded 0.70 .

\section{Statistical Treatment}

To answer the study questions, the following statistical processes were used through the SPSS:

- Frequencies and percentages of the personal and functional members of the study sample.

- Arithmetic means and standard deviations for the answers of the study sample about all fields of the study tool.

- One- Sample t-Test.

- Independent - Sample T. Test.

- The scale was corrected and adopted to measure the arithmetic means as follows:

- Less than 2.33-low.

- 2.34-3.66- average.

- 3.67 - 5.00- high.

\section{Results}

This chapter includes a presentation of the results of the study that aimed to know the degree of accountability in the Jordanian public and private universities. However, they are presented in three parts according to the study questions.

\section{Results Related to the First Question}

The first question is: What is the degree of applying the principles of accountability at Yarmouk University from the perspective of employees at the university: faculty members and administrators? To answer this question, the arithmetic means and standard were calculated. Also, One- Sample TTest was applied to detect the degree of applying the principles of 


\section{accountability. Thus, such results will be presented according to the fields of} the study in both universities.

\section{- Administrative and Academic Field}

First: Table 3. Arithmetic means and criterion deviations for the items of

"administrative area" and "academic field" in the internal and external level, and the whole level of Yarmouk University $(\mathrm{n}=150)$

\begin{tabular}{|c|c|c|c|c|c|}
\hline No & $\begin{array}{c}\text { Item / the internal level of the } \\
\text { "administrative field" of Yarmouk } \\
\text { University }\end{array}$ & Arithmetic mean & $\begin{array}{l}\text { Standard } \\
\text { deviation }\end{array}$ & Rank & Degree \\
\hline 1 & $\begin{array}{l}\text { There are efficient organizational } \\
\text { structures at universities where the } \\
\text { responsibilities and authorities are } \\
\text { equally distributed in the various } \\
\text { administrative levels, which } \\
\text { facilitates the process of } \\
\text { accountability. }\end{array}$ & 3.69 & 0.91 & 1 & high \\
\hline 2 & $\begin{array}{l}\text { Universities depend on performance } \\
\text { criteria as a tool of control to } \\
\text { evaluate the administrative process } \\
\text { which facilitates accountability. }\end{array}$ & 3.44 & 0.94 & 2 & medium \\
\hline 3 & $\begin{array}{l}\text { Recruitment is based on scientific } \\
\text { methods to assess the need for } \\
\text { human resources in regards with } \\
\text { quality and quantity, and it is } \\
\text { accountable. }\end{array}$ & 3.27 & 1.03 & 4 & medium \\
\hline 4 & $\begin{array}{l}\text { Universities rely on the calculation } \\
\text { of the time of the actual operation of } \\
\text { the employees and comparing it with } \\
\text { the total paid-up time to reduce the } \\
\text { costs arising from recruiting the } \\
\text { human resources, and they are } \\
\text { accountable. }\end{array}$ & 3.18 & 1.12 & 6 & medium \\
\hline 5 & $\begin{array}{l}\text { Universities re-engineer the } \\
\text { administrative processes in } \\
\text { accordance with the technical and } \\
\text { technological development to } \\
\text { provide the best service, and they are } \\
\text { accountable. }\end{array}$ & 3.33 & 1.06 & 3 & medium \\
\hline 6 & $\begin{array}{l}\text { Universities adopt written, declared, } \\
\text { and effective behavioral codes; they } \\
\text { are the subject of interest in various } \\
\text { administrative levels. }\end{array}$ & 3.25 & 1.18 & 5 & medium \\
\hline \multicolumn{2}{|c|}{$\begin{array}{l}\text { The internal level of the "administrative } \\
\text { level" as a whole for Yarmouk University }\end{array}$} & 3.36 & 0.67 & - & medium \\
\hline No & $\begin{array}{c}\text { Item/ the external level of the } \\
\text { "administrative field" for Yarmouk } \\
\text { University }\end{array}$ & & & & \\
\hline 1 & $\begin{array}{l}\text { The Ministry of Higher Education } \\
\text { and the Higher Education } \\
\text { Accreditation Commission of } \\
\text { universities require that the } \\
\text { universities develop clear strategic } \\
\text { plans which contain the vision, } \\
\text { mission, and objectives. They are } \\
\text { accountable. }\end{array}$ & 3.48 & 1.02 & 2 & $\overline{\text { medium }}$ \\
\hline 2 & $\begin{array}{l}\text { The Ministry of Higher Education } \\
\text { and the Higher Education } \\
\text { Accreditation Commission require }\end{array}$ & 3.20 & 1.14 & 6 & medium \\
\hline
\end{tabular}




\begin{tabular}{|c|c|c|c|c|c|}
\hline & $\begin{array}{l}\text { that universities should set a guide } \\
\text { that includes the duties and rights of } \\
\text { staff, faculty members, and support } \\
\text { cadre; hence, they are accountable. }\end{array}$ & & & & \\
\hline 3 & $\begin{array}{l}\text { The Ministry of Higher Education } \\
\text { and the Higher Education } \\
\text { Accreditation Commission require } \\
\text { that universities should determine } \\
\text { the organizational and administrative } \\
\text { structure of the University which is } \\
\text { accountable. }\end{array}$ & 3.29 & 1.21 & 5 & medium \\
\hline 4 & $\begin{array}{l}\text { The Ministry of Higher Education } \\
\text { and the Higher Education } \\
\text { Accreditation Commission oblige } \\
\text { that universities should prepare the } \\
\text { necessary regulations in line with the } \\
\text { law of universities and it is } \\
\text { accountable. }\end{array}$ & 3.71 & 1.00 & 1 & high \\
\hline 5 & $\begin{array}{l}\text { The Ministry of Higher Education } \\
\text { and the Higher Education } \\
\text { Accreditation Commission have the } \\
\text { tools necessary to measure the } \\
\text { performance of universities and it is } \\
\text { accountable. }\end{array}$ & 3.42 & 0.82 & 3 & medium \\
\hline 6 & $\begin{array}{l}\text { The Ministry of Higher Education } \\
\text { and the Higher Education } \\
\text { Accreditation Commission impose } \\
\text { the integrity and transparency } \\
\text { criteria on universities. }\end{array}$ & 3.32 & 0.99 & 4 & medium \\
\hline \multicolumn{2}{|c|}{$\begin{array}{l}\text { The external level of the "administrative } \\
\text { field" as a whole for Yarmouk University }\end{array}$} & 3.40 & 0.66 & - & medium \\
\hline No & $\begin{array}{c}\text { Item / the internal level of "the } \\
\text { academic field" for Yarmouk } \\
\text { University }\end{array}$ & & & & \\
\hline 1 & $\begin{array}{c}\text { Universities adopt clear criteria for } \\
\text { calculating the capacity in terms of } \\
\text { the number of the approved students } \\
\text { on which approving students depend, } \\
\text { and they are accountable. }\end{array}$ & 3.22 & 1 & 5 & medium \\
\hline 2 & $\begin{array}{l}\text { The criterion of the number of } \\
\text { students in different disciplines is the } \\
\text { main determinant of the required } \\
\text { number of the faculty members } \\
\text { which is accountable. }\end{array}$ & 3.20 & 1.11 & 6 & medium \\
\hline 3 & $\begin{array}{l}\text { The diversity of the sources of } \\
\text { doctorate certificates is taken into } \\
\text { account and it is accountable. }\end{array}$ & 3.65 & 1.02 & 1 & medium \\
\hline 4 & $\begin{array}{l}\text { The development of departments and } \\
\text { specialties is done according to the } \\
\text { criteria and conditions of accrediting } \\
\text { certain programs and specialties set } \\
\text { out in the laws, and this is } \\
\text { accountable. }\end{array}$ & 3.45 & 0.99 & 3 & medium \\
\hline 5 & $\begin{array}{l}\text { Universities adapt the criteria of the } \\
\text { higher education institutions of } \\
\text { quality and they are accountable. }\end{array}$ & 3.39 & 1.07 & 4 & medium \\
\hline 6 & $\begin{array}{l}\text { Universities set the mission, targets } \\
\text { and expectation, and a clear and } \\
\text { declared learning outcomes for each } \\
\text { specialty that are compatible with the } \\
\text { overall vision, mission, and }\end{array}$ & 3.49 & 1.07 & 2 & medium \\
\hline
\end{tabular}




\begin{tabular}{|c|c|c|c|c|c|}
\hline & $\begin{array}{l}\text { objectives of the faculty. Also, they } \\
\text { are accountable. }\end{array}$ & & & & \\
\hline \multicolumn{2}{|c|}{$\begin{array}{l}\text { Item/ the internal level of the "academic } \\
\text { field" of Yarmouk University }\end{array}$} & 3.40 & 0.57 & - & medium \\
\hline No & $\begin{array}{l}\text { Item/the external level of the } \\
\text { "academic field" of Yarmouk } \\
\text { University }\end{array}$ & & & & \\
\hline 1 & $\begin{array}{l}\text { The Ministry of Higher Education } \\
\text { and the Higher Education } \\
\text { Accreditation Commission practice } \\
\text { their controlling role for the } \\
\text { universities' commitment of the } \\
\text { criteria of calculating the absorbing } \\
\text { capacity of universities, which is } \\
\text { accountable. }\end{array}$ & 3.30 & 1.05 & 4 & medium \\
\hline 2 & $\begin{array}{l}\text { The Ministry of Higher Education } \\
\text { and the Higher Education } \\
\text { Accreditation Commission practice } \\
\text { their controlling role for the } \\
\text { universities' commitment of the } \\
\text { criteria of calculating the number of } \\
\text { faculty members in various } \\
\text { programs, which is accountable. }\end{array}$ & 3.19 & 1.04 & 5 & medium \\
\hline 3 & $\begin{array}{l}\text { The Ministry of Higher Education } \\
\text { and the Higher Education } \\
\text { Accreditation Commission practice } \\
\text { their controlling role for the } \\
\text { universities' compliance with } \\
\text { diversity in the sources of doctoral } \\
\text { degrees for the faculty members, } \\
\text { which is accountable. }\end{array}$ & 3.34 & 1.09 & 3 & medium \\
\hline 4 & $\begin{array}{l}\text { The Ministry of Higher Education } \\
\text { and the Higher Education } \\
\text { Accreditation Commission practice } \\
\text { their controlling role for the } \\
\text { universities' compliance with the } \\
\text { minimum space allocated to each } \\
\text { student in the teaching area of the } \\
\text { scientific and humanitarian } \\
\text { specialties, which is accountable. }\end{array}$ & 3.43 & 0.99 & 1 & medium \\
\hline 5 & $\begin{array}{l}\text { The Ministry of Higher Education } \\
\text { and the Higher Education } \\
\text { Accreditation Commission conduct } \\
\text { their controlling tasks towards public } \\
\text { and private universities equally and } \\
\text { without discrimination. }\end{array}$ & 3.42 & 1.11 & 2 & medium \\
\hline 6 & $\begin{array}{l}\text { The Ministry of Higher Education } \\
\text { and the Higher Education } \\
\text { Accreditation Commission practice } \\
\text { their controlling role in attacking the } \\
\text { private universities, while the public } \\
\text { universities are above accountability. }\end{array}$ & 3.07 & 1.11 & 6 & medium \\
\hline & $\begin{array}{l}\text { ernal level of the "academic field" as } \\
\text { whole for Yarmouk University }\end{array}$ & 3.29 & 0.64 & - & medium \\
\hline
\end{tabular}

1. Table 3 shows that the arithmetic means of the items of the internal level "of the administrative field" and the level as a whole of Yarmouk University ranged between 3.18-3.69; the highest was item (1) moderately; 
and the internal level as a whole for Yarmouk University was (3.34) in a moderate degree.

- The arithmetic means of the items of the external level for the "administrative field" and the level as a whole for Yarmouk University ranged between 3.20-3.71; the highest was for item No. (4), and the lowest was item (2) moderately; and the external level as a whole for Yarmouk University was (3.40) moderately.

2. The arithmetic means of the items of the internal level for the "academic field" and the level as a whole for Yarmouk University were 3.203.65; the highest was item No. (3) moderately, and the lowest was item (2) moderately; and the arithmetic mean for the internal level of the "academic field" as a whole for Yarmouk University was (3.40) in a moderate degree.

- The arithmetic means for the items of the "external level" of the "academic level" and the level as a whole for Yarmouk University were between 3.07-3.43; the highest was item No. (4) Moderately; and the lowest was item No. (6) moderately. The arithmetic mean for the external level of the "academic field" as a whole for Yarmouk University was (3.29) in a moderate degree.

* One- Sample T-Test was used in detecting the degree of applying the principles of accountability at Yarmouk University from the perspective of employees at the university: the teaching staff and administrators.

Table 4. One- Sample T-Test results to detect the degree of applying the principles of accountability from the perspective of the employees at the university: teaching staff and administrators

\begin{tabular}{|c||c|c|c|c|c|}
\hline $\begin{array}{c}\text { What is the degree of applying the } \\
\text { principles of accountability at } \\
\text { Yarmouk University from the }\end{array}$ & Mean & $\begin{array}{c}\text { Standard } \\
\text { deviation }\end{array}$ & $\begin{array}{c}\text { Degrees of } \\
\text { freedom }\end{array}$ & t-value & $p$. value \\
\cline { 2 - 6 } $\begin{array}{c}\text { perspective of employees at the } \\
\text { university: teaching staff and } \\
\text { administrators? }\end{array}$ & 3.36 & 0.50 & 149 & 8.81 & 0.00 \\
\hline
\end{tabular}

Table 4 shows that the value of $t$ was 8.810 by a statistical significance of 0.00 . Here, the general mean was compared with the standard value of the quintet gradation, namely: (3) The results showed the presence of an average and statistically significant degree in the application of the principles of accountability at Yarmouk University from the perspective of employees at the two universities.

\section{Results for the Second Question}

The second question relates to the degree of applying the principles of accountability at Jerash University from the perspective of employees at the university: teaching staff and administrators. In answering this question, "What is the arithmetic means and standard deviations of the principles of 
accountability at Jerash University from the perspective of teaching staff and administrators at the university”, a one- Sample T-Test is applied. However, the tables below illustrate this.

\section{The Administrative and Academic Fields}

Table 5. The arithmetic means and standard deviations for the items of the "administrative area" and the "academic field" in the internal and external levels and the level as a whole for Jerash University $(\mathrm{n}=100)$.

\begin{tabular}{|c|c|c|c|c|c|}
\hline No & $\begin{array}{l}\text { Item/ the internal level of the } \\
\text { "administrative field" of Jerash } \\
\text { University }\end{array}$ & Arithmetic mean & $\begin{array}{l}\text { Standard } \\
\text { deviation }\end{array}$ & Rank & Degree \\
\hline 1 & $\begin{array}{l}\text { There are efficient organizational } \\
\text { structures at universities where the } \\
\text { responsibilities and authorities are } \\
\text { equally distributed in the various } \\
\text { administrative levels, which } \\
\text { facilitates the process of } \\
\text { accountability. }\end{array}$ & 3.43 & 1 & 1 & medium \\
\hline 2 & $\begin{array}{l}\text { Universities depend on performance } \\
\text { criteria as a tool of control to } \\
\text { evaluate the administrative process } \\
\text { which facilitates accountability. }\end{array}$ & 3.41 & 0.98 & 2 & medium \\
\hline 3 & $\begin{array}{l}\text { Recruitment is based on scientific } \\
\text { methods to assess the need for } \\
\text { human resources with regards to } \\
\text { quality and quantity, and it is } \\
\text { accountable. }\end{array}$ & 3.12 & 1.15 & 6 & medium \\
\hline 4 & $\begin{array}{l}\text { Universities rely on the calculation } \\
\text { of the time of the actual operation of } \\
\text { the employees and comparing it with } \\
\text { the total paid-up time to reduce the } \\
\text { costs arising from recruiting the } \\
\text { human resources, and they are } \\
\text { accountable. }\end{array}$ & 3.22 & 1.13 & 5 & medium \\
\hline 5 & $\begin{array}{l}\text { Universities re-engineer the } \\
\text { administrative processes in } \\
\text { accordance with the technical and } \\
\text { technological development to } \\
\text { provide the best service, and they are } \\
\text { accountable. }\end{array}$ & 3.33 & 1.09 & 4 & medium \\
\hline 6 & $\begin{array}{c}\text { Universities adopt written, declared, } \\
\text { and effective behavioral codes; } \\
\text { however, they are the subject of } \\
\text { interest in many administrative } \\
\text { levels }\end{array}$ & 3.36 & 1.03 & 3 & medium \\
\hline \multicolumn{2}{|c|}{$\begin{array}{l}\text { The internal level of the "administrative } \\
\text { level" as a whole for Jerash University }\end{array}$} & 3.31 & 0.71 & - & medium \\
\hline No & $\begin{array}{l}\text { The external level of the } \\
\text { "administrative level" as a whole for } \\
\text { Jerash University }\end{array}$ & & & & \\
\hline 1 & $\begin{array}{l}\text { The Ministry of Higher Education } \\
\text { and the Higher Education } \\
\text { Accreditation Commission of } \\
\text { universities require that the } \\
\text { universities develop clear strategic } \\
\text { plans which contain the vision, } \\
\text { mission, and objectives. They are }\end{array}$ & 3.64 & 1.10 & 2 & medium \\
\hline
\end{tabular}




\begin{tabular}{|c|c|c|c|c|c|}
\hline & accountable. & & & & \\
\hline 2 & $\begin{array}{l}\text { The Ministry of Higher Education } \\
\text { and the Higher Education } \\
\text { Accreditation Commission require } \\
\text { that universities set a guide that } \\
\text { includes the duties and rights of the } \\
\text { staff, faculty members, and support } \\
\text { cadre which are all accountable. }\end{array}$ & 3.48 & 1.18 & 4 & medium \\
\hline 3 & $\begin{array}{l}\text { The Ministry of Higher Education } \\
\text { and the Higher Education and } \\
\text { Accreditation Commission require } \\
\text { that universities should determine } \\
\text { the organizational and administrative } \\
\text { structure of the University which is } \\
\text { accountable. }\end{array}$ & 3.47 & 1.14 & 5 & medium \\
\hline 4 & $\begin{array}{l}\text { The Ministry of Higher Education } \\
\text { and the Higher Education } \\
\text { Accreditation Commission oblige } \\
\text { universities to prepare the necessary } \\
\text { regulations in line with the law of } \\
\text { universities and monitor compliance } \\
\text { with it. Also, it is accountable. }\end{array}$ & 3.87 & 0.99 & 1 & High \\
\hline 5 & $\begin{array}{l}\text { The Ministry of Higher Education } \\
\text { and the Higher Education } \\
\text { Accreditation Commission have the } \\
\text { tools necessary to measure the } \\
\text { performance of universities, and it is } \\
\text { accountable. }\end{array}$ & 3.58 & 0.84 & 3 & medium \\
\hline 6 & $\begin{array}{l}\text { The Ministry of Higher Education } \\
\text { and the Higher Education } \\
\text { Accreditation Commission impose } \\
\text { the integrity and transparency } \\
\text { criteria on universities }\end{array}$ & 3.42 & 1.05 & 6 & medium \\
\hline \multicolumn{2}{|c|}{$\begin{array}{l}\text { The external level of the "administrative } \\
\text { field" as a whole for Jerash University }\end{array}$} & 3.58 & 0.75 & - & medium \\
\hline No & $\begin{array}{c}\text { Item / the internal level of "the } \\
\text { academic field" for Jerash University }\end{array}$ & & & & \\
\hline 1 & $\begin{array}{l}\text { Universities adopt clear criteria for } \\
\text { calculating the capacity in terms of } \\
\text { the number of the approved students } \\
\text { on which approving students depend, } \\
\text { and they are accountable. }\end{array}$ & 3.61 & 1.13 & 6 & medium \\
\hline 2 & $\begin{array}{l}\text { The criterion of the number of } \\
\text { students in different disciplines is the } \\
\text { main determinant of the required } \\
\text { number of the faculty members } \\
\text { which is accountable. }\end{array}$ & 3.71 & 1.10 & 4 & High \\
\hline 3 & $\begin{array}{l}\text { The diversity of the sources of } \\
\text { doctorate certificates is taken into } \\
\text { account and it is accountable. }\end{array}$ & 3.85 & 0.96 & 1 & High \\
\hline 4 & $\begin{array}{l}\text { The development of departments and } \\
\text { specialties is done according to the } \\
\text { criteria and conditions of accrediting } \\
\text { certain programs and specialties set } \\
\text { out in the regulations and laws, and } \\
\text { this is accountable. }\end{array}$ & 3.76 & 1.03 & 2 & High \\
\hline 5 & $\begin{array}{l}\text { Universities adapt the criteria of the } \\
\text { higher education institutions of } \\
\text { quality, and they are accountable. }\end{array}$ & 3.65 & 1.11 & 5 & medium \\
\hline 6 & Universities set the mission, targets & 3.74 & 1.11 & 3 & High \\
\hline
\end{tabular}




\begin{tabular}{|c|c|c|c|c|c|}
\hline & $\begin{array}{c}\text { and expectation, and clear and } \\
\text { declared learning outcomes for each } \\
\text { specialty that are compatible with the } \\
\text { overall vision, mission, and } \\
\text { objectives of the faculty, and they } \\
\text { are accountable. }\end{array}$ & & & & \\
\hline \multicolumn{2}{|c|}{$\begin{array}{l}\text { Item/ the internal level of the "academic } \\
\text { field" of Jerash University }\end{array}$} & 3.72 & 0.74 & - & High \\
\hline no & $\begin{array}{c}\text { Item/ the external level of the } \\
\text { "academic field" of Jerash University }\end{array}$ & & & & \\
\hline 1 & $\begin{array}{l}\text { The Ministry of Higher Education } \\
\text { and the Higher Education } \\
\text { Accreditation Commission practice } \\
\text { their controlling role for the } \\
\text { universities' commitment of the } \\
\text { criteria of calculating the absorbing } \\
\text { capacity of universities, which is } \\
\text { accountable. }\end{array}$ & 3.74 & 1.11 & 1 & High \\
\hline 2 & $\begin{array}{l}\text { The Ministry of Higher Education } \\
\text { and the Higher Education } \\
\text { Accreditation Commission practice } \\
\text { their controlling role for the } \\
\text { universities' commitment of the } \\
\text { criteria of calculating the number of } \\
\text { faculty members in various } \\
\text { programs, which is accountable. }\end{array}$ & 3.63 & 1.17 & 3 & medium \\
\hline 3 & $\begin{array}{l}\text { The Ministry of Higher Education } \\
\text { and the Higher Education } \\
\text { Accreditation Commission practice } \\
\text { their controlling role for the } \\
\text { universities' compliance with } \\
\text { diversity in the sources of doctoral } \\
\text { degrees for the faculty members, } \\
\text { which is accountable. }\end{array}$ & 3.58 & 1.11 & 4 & medium \\
\hline 4 & $\begin{array}{l}\text { The Ministry of Higher Education } \\
\text { and the Higher Education } \\
\text { Accreditation Commission practice } \\
\text { their controlling role for the } \\
\text { universities' compliance with the } \\
\text { minimum space allocated to each } \\
\text { student in the teaching area of the } \\
\text { scientific and humanitarian } \\
\text { specialties, which is accountable. }\end{array}$ & 3.68 & 1.02 & 2 & High \\
\hline 5 & $\begin{array}{l}\text { The Ministry of Higher Education } \\
\text { and the Higher Education } \\
\text { Accreditation Commission conduct } \\
\text { their controlling tasks towards public } \\
\text { and private universities equally and } \\
\text { without discrimination. }\end{array}$ & 3.42 & 1.23 & 6 & medium \\
\hline 6 & $\begin{array}{l}\text { The Ministry of Higher Education } \\
\text { and the Higher Education } \\
\text { Accreditation Commission practice } \\
\text { their controlling role in attacking the } \\
\text { private universities while the public } \\
\text { universities are above accountability. }\end{array}$ & 3.50 & 1.26 & 5 & medium \\
\hline & $\begin{array}{l}\text { ternal level of the "academic field" as } \\
\text { a whole for Jerash University }\end{array}$ & 3.59 & 0.74 & - & medium \\
\hline
\end{tabular}


1, Table 5 shows that the arithmetic means of the internal level of the "administrative field" and the level as a whole for Jerash University ranged between 3.12-3.43; the highest was item (1) in a moderate degree and the lowest was item No. (3) also moderately; and the arithmetic mean for the internal level for "the administrative field" as a whole for Jerash University was (3.31) in a moderate degree.

- The arithmetic means for the items of the external level of "the administrative field" and the level as a whole for Jerash University ranged between 3.42 -3.87; the highest was item No. (4) in a moderate degree and the lowest was item No. (6) in a moderate degree. As for the arithmetic mean of the external level of the "administrative field" as a whole for Jerash University, it was moderately (3.85).

2. The arithmetic means for the items of the internal level of the "academic field" and the whole level of Jerash University were 3.42 -3.74, and the highest was item (1) moderately and the lowest was item No. 5 also moderately.

- The arithmetic mean of the external level of "the academic field" as a whole for Jerash University was (3.31) in a moderate degree, while the external level of "the academic field" as a whole for Jerash University was (3.58) moderately.

* One- Sample T-Test was used to detect the degree of applying the principles of accountability at Jerash University from the perspective of the employees at the university: the teaching staff and administrators.

Table 6. One- Sample T-Test results to detect the principles of accountability in Jerash University from the perspective of employees at the university: the faculty members and the administrators.

\begin{tabular}{|c|c|c|c|c||c|}
\hline $\begin{array}{c}\text { What is the degree of applying the } \\
\text { principles of accountability at Jerash } \\
\text { University from the perspective of } \\
\text { employees at the university: teaching } \\
\text { staff and administrators? }\end{array}$ & Mean & $\begin{array}{c}\text { Standard } \\
\text { deviation }\end{array}$ & $\begin{array}{c}\text { Degrees of } \\
\text { freedom }\end{array}$ & $\begin{array}{c}\text { T- } \\
\text { value }\end{array}$ & p. value \\
\cline { 2 - 6 } & 3.55 & 0.59 & 99 & 9.25 & 0.00 \\
\hline
\end{tabular}

Table 6 shows that the value of $t$ was 9.25 by a statistical significance of 0.00 ; here, the general mean of the standard of the quintet gradation was No. (3). However, the results showed the presence of moderate and statistically significant results in applying the principles of accountability at Jerash University from the perspective of the employees of the university: teaching staff and administrators.

\section{Results Related to the Third Question}

The third question is: are there statistically significant differences between the two universities in the degree of applying the principles of accountability at the level of significance $\alpha \leq 0.05$ ? To answer this question, 
the arithmetic means and standard deviations for the fields of applying accountability at the two universities were calculated. However, to detect the differences between these means, Independent - Sample T- Test was used and table 7 illustrates this.

Table 7. Independent - Sample T-Test results for the detection of differences for the reality of applying accountability at both Universities

\begin{tabular}{|c|c|c|c|c|c|c|}
\hline Field & University & No & Mean & $\begin{array}{l}\text { Standard } \\
\text { deviation }\end{array}$ & $\begin{array}{c}\text { "t" } \\
\text { Value } \\
\end{array}$ & p.value \\
\hline \multirow{2}{*}{$\begin{array}{c}\text { The } \\
\text { Administrative } \\
\text { field }\end{array}$} & Yarmouk & 150 & 3.40 & 0.66 & \multirow[b]{2}{*}{1.94} & \multirow[b]{2}{*}{0.05} \\
\hline & Jerash & 100 & 3.58 & 0.75 & & \\
\hline \multirow{2}{*}{ The financial field } & Yarmouk & 150 & 3.15 & 0.66 & \multirow{2}{*}{2.67} & \multirow{2}{*}{0.01} \\
\hline & Jerash & 100 & 3.39 & 0.73 & & \\
\hline \multirow{2}{*}{$\begin{array}{l}\text { The academic } \\
\text { field }\end{array}$} & Yarmouk & 150 & 3.29 & 0.64 & \multirow{2}{*}{3.41} & \multirow{2}{*}{0.00} \\
\hline & Jerash & 100 & 3.59 & 0.74 & & \\
\hline \multirow[b]{2}{*}{$\begin{array}{l}\text { The reality of } \\
\text { applying } \\
\text { accountability at } \\
\text { the public and } \\
\text { private } \\
\text { universities in } \\
\text { Jordan }\end{array}$} & Yarmouk & 150 & 3.33 & 0.49 & & \\
\hline & Jerash & 100 & 3.52 & 0.60 & 2.70 & 0.01 \\
\hline
\end{tabular}

Consequently, Table 7 shows the following:

- There are statistically significant differences at the level of significance $(\alpha \leq 0.05)$ in the administrative field according to the variable of the university, as the value of "t" was 1.94 by a statistical significance of 0.05 in favor of Jerash University.

- There are statistically significant differences at the level of significance $(\alpha \leq 0.05)$ in the financial field according to the variable of the university, as the value of "t" was 2.67 by a statistical significance of 0.01 in favor of Jerash University.

- There are statistically significant differences at the level of significance $(\alpha \leq 0.05)$ in the academic field according to the variable of the university, as the value of " $\mathrm{t}$ " was 3.41 by a statistical significance of 0.000 in favor of Jerash University.

- There are statistically significant differences at the level of significance $(\alpha \leq 0.05)$ in the reality of applying accountability in the Jordanian public and private universities according to the variable of the university, as the value of "t" was 2.70 by a statistical significance of 0.01 in favor of Jerash University.

\section{Summary of Results}

- $\quad$ The results showed a moderate and statistically significant degree in applying the principles of accountability at Yarmouk University from the 
perspective of the employees at the University: teaching staff and administrators.

- $\quad$ The results showed a moderate and statistically significant degree in applying the principles of accountability at Jerash University from the perspective of the employees at the University: teaching staff and administrators.

- $\quad$ The results showed that there are statistically significant differences at the level of significance $(\alpha \leq 0.05)$ in the reality of applying accountability in the Jordanian public and private universities according to the variable of the university in favor of Jerash University.

\section{Interpretation of Results}

The study showed that accountability in the public and private universities in Jordan have a moderated degree in both the administrative and academic fields in the internal and external levels. Also, the control levels at the private universities are higher than those in the public universities. However, this is due to the fact that the criteria applied in the private universities are varied and comprehensive. In addition, the control is more effective in the public universities.

\section{Recommendations}

In the light of the findings, the study recommends the following:

- Activating the administrative and academic accountability in the Jordanian public and private universities in a larger degree which will positively reflect on the work of universities.

- Subjecting the Jordanian public and private universities to unified criteria in accountability so as to achieve a great deal of fairness and transparency, and which is required the more in public universities.

\section{References:}

1. Akho Arashaidah Alia. (2004). The degree of the awareness of male and female teachers in the public secondary schools with the concept of accountability and its relationship to the school efficiency. Unpublished doctoral dissertation, Amman Arab University for Graduate Studies: Jordan.

2. Al-Allaq Bashir (2008). Modern management: theories and concepts, Amman: Al-Yazouri House for publication and distribution.

3. Al-Hassan Mai (2010). The degrees of the administrative accountability and the effectiveness and the relation between them among the public school male and female principles in the West Bank provinces from the perspective of employees in the departments of Education, Master Thesis, Al-Najah University, Nablus, Palestine. 
4. Al-Jahni Mohammed (2012). After the comprehensive educational assessment, is there an educational accountability? Al-Marefa Magazine. www.almarefah.com/print.php?id=1755.

5. Al-Subaie Fares (2010). The role of transparency and accountability in the reduction of the administrative corruption in the governmental sectors, unpublished $\mathrm{PhD}$ Thesis, Naif Arab University for Security Sciences, Riyadh.

6. Bajaria, H. (2011). Effective TQM Implementation: Critical Issues. Multiface, Inc. Michigan.

7. Deboer Harry; Huisman Jeroen \& Meister-Scheytt Claudia (2010). Supervision in "Modern" University Governance: Boards under Scrutiny. Studies in Higher Education, 35 (3) p317-333.

8. Dwairy Ahmed (2002) accountability in public administration in Jordan: an Analytical field study from the perspective of managers in the Ministry of Administrative Development and the central control devices. "Unpublished MA Thesis, Yarmouk University, Jordan.

9. Gasman \& Marybeth (2010). Five Lessons for Campus Leaders: Academic Freedom, Shared Governance, and Tenure at an Historically Black University. Change: The Magazine of Higher Learning, 42 (6) p54-57.

10. Harb Nuaima Mohammed (2011). The reality of administrative transparency and the requirements of applying it in the Palestinian universities in the Gaza Strip. Unpublished MA Thesis, Islamic University of Gaza.

11. Hawamdeh Basem Ali and Jaradat Mohammad Hassan (2005). The degree of applying the administrative accountability in the public schools in Jerash, the Faculty of Education Journal, Al-Mansoura University, No. 58, Part II.

12. Jamil Ghalib (2009). Something of politics: transparency and accountability in public organizations, a presentation of the experiences of some Arab countries. September 26 newspaper http://www.26sep.net.

13. Klatt Murphy (2002) .Frequently Asked Questions. From: www.murphyklatt.com/fags.html. Retrieved 28/2/2002.

14. Romzek Barbara S. and Dubnick, Melvin J., (2008) Accountability in the Public Sector: Lessons from the Challenger, Public Administration Review, 47 (3) available at: http://www.jstor.org/stable (975 901).

15. United Nations Development Program (2006). Institutional Reform and Change Management: Managing Change in Public Sector Organization. Bureau for Development Policy, United Nations Development Program 